Pavol Jozef Šafárik Egyetem, Általános Orvostudományi Kar, Gyermekgyógyászati Klinika, Kassa, ${ }^{1}$ Miskolci Egyetem, Egészségügyi Kar, Elméleti Egészségtudományi Intézet, Miskolc, ${ }^{2}$ Markhot Ferenc Oktatókórház, Gyermekgyógyászati Osztály, Eger ${ }^{3}$

\title{
A diabeteses beteg átadása a gyermekgondozásból a felnőttgondozásba - Mit mondanak az ajánlások?
}

\author{
Barkai László dr. ${ }^{(1,2,3)}$
}

\begin{abstract}
A diabeteses gyermekek felnőttgondozásba történő átadás-átvétele jelentős kihívás mind az érintettek, mind a gondozók számára. E kérdéskört tǔzte programjára 2017-ben az MDT Gyermekdiabetes Szekció miskolctapolcai tudományos ülésén a folyamatot részben az átadó, részben az átvevő szemszögéből vizsgálva. A nagy érdeklődésre és az élénk megbeszélésre tekintettel a szerkesztőség felkérte a vitavezető Barkai professzor urat és a két előadót előadásaik közlemény formájában történő megírására. Ezt adjuk most közre.
\end{abstract}

\section{Összefoglalás}

A diabetes incidenciája és prevalenciája a fiatalok körében növekszik. A fiatal felnöttkor nem közvetlenül a serdülökor után következik, az adoleszcens idöszak után ún. „fejlödö felnöttkor"-ról beszélünk, amely szociális értelemben a serdülökor meghosszabbitásaként értelmezhetö. A szülök szerepe és a gondozás folyamata alapvetöen átalakul a gyermekkor-felnöttkor határán. Fokozott kockázatot jelent a rossz anyagcsere, a szövödmények kialakulása, a kockázatkeresö magatartásformák, valamint a pszichés és mentálhigiénés problémák. A legnagyobb veszélyt a beteg gondozásból való kiesése jelenti. A sikeres betegátadás-átvétel folyamatának biztositására nincsenek igazolt evidenciák és modellek. A szövödmények elkerülése érdekében azonban megtervezett, jól szervezett, individualizált és flexibilis átadásra van szükség, amelynek során az együttmüködés az átadó és az átvevö gondozók között elengedhetetlen.

Kulcsszavak: gyermek, serdülö, fejlödö felnött, fiatal felnött, diabetes

\section{Transition of the patient with diabetes from pediatric to adult care. What do the recommendations say?}

Summary: The incidence and prevalence of diabetes in youths are increasing. Young adulthood does not immediately follow adolescence: "emerging adulthood" is the extension period of adolescent years. Family support and diabetes care services are substantially different for pediatric, adolescent and emerging adult patients. Poor metabolic control, development of acute and chronic complications, risk behaviour, psychological and mental health problems are the main risk factors, but lost to follow-up is the biggest issue for the outcome. No proven strategy or evidence based model is available for successful transition. However, planned, organized, individualized and flexible transfer is needed and cooperation between services are essential to overcome existing issues and avoid complications in the transition from pediatric to adult diabetes care.

Key words: child, adolescent, emerging adult, young adult, diabetes

Röviditések

ISPAD: Nemzetközi Gyermek- és Serdülökori Diabetes Társaság (International Society for Pediatric and Adolescent Diabetes) 
A gyermekkori cukorbetegség gyakorisága világszerte növekvő tendenciát mutat. Az 1-es típusú cukorbetegség incidenciája - jól ismert módon - a megelőző évtizedekben a nemzetközi és hazai adatok szerint is jelentősen emelkedett, elsősorban a serdülés időszakában, illetve a kisgyermekkorban. ${ }^{1}$ A 2-es típusú cukorbetegség korábban szinte kizárólagosan a felnőttkor betegsége volt, azonban a 90-es évek elejétől - elsősorban az Egyesült Államokban - megszaporodtak azok a közlések, amelyek a gyermekkori elhízás gyakoriságának emelkedésével párhuzamosan a 2-es típusú diabetes szaporodó megjelenéséről tudósítottak a serdülőkorban. ${ }^{2}$ Ezen folyamatok eredményeként, túl azon, hogy a gyermek-, serdülőés fiatal felnőttkorban a cukorbetegek számaránya egyre nagyobb, egyre gyakoribb kihívást jelent a páciensek átadása a gyermekgyógyászati gondozásból a felnőttellátásba. Az átadás-átvétel kérdésköre életkori-biológiai tényezőket, szociológiai-ökonómiai kérdéseket és speciális diabetológiai aspektusokat érint, amelyek meghatározzák ennek az átmeneti és nem rövid periódusnak a lehetőségeit, körülményeit. A jelen összefoglalás a témával foglalkozó nemzetközi szakmai állásfoglalások, ajánlások segítségével kívánja áttekinteni a kérdéskört.

\section{Fejlődési szakaszok}

A fejlődési szakaszokat terminológiai értelemben gyermek-, serdülő-, fiatal felnőtt- és felnőttkorra szokás osztani. Napjainkban a fejlett társadalmakban a gyermekgyógyászati ellátás feladata a gyermek- és serdülőkorú betegek ellátása, az ennél idősebb korosztály egészségügyi ellátása ebben az értelemben a felnőttgyógyászat kompetenciája. Mindez természetesen érvényes a krónikus betegek, köztük a cukorbetegek ellátására, gondozására is, aminek értelmében az átadás-átvétel problematikája a serdülő- és a fiatal felnőtt korú betegeket és az őket ellátó szakembereket érinti elsősorban.

A szakirodalom egységes a serdülő (adoleszcens) életkor definiálását illetően. Az Egészségügyi Világszervezet (WHO) ezt a kort a 10-19 éves korcsoportra vonatkoztatja, amelyet a szükebb értelmű megfogalmazás szerint a testi és emocionális változásokkal, reproduktív érettség kialakulásával jellemzi, tágabb értelemben azonban ide sorolja a pszichológiai, szociális és morális változások folyamatát is. ${ }^{3}$ A Nemzetközi Gyermek- és Serdülőkori Diabetes Társaság, (ISPAD: International Society for Pediatric and Adolescent Diabetes) definíciója a gyermekkor és felnőttkor közötti időszakot a pubertás biológiai és pszichoszociális változásaival jellemzi, ${ }^{4}$ ami lényegében csaknem azonos a WHO meghatározásával.

A fiatal felnőtt megítélése azonban már nem tekinthető egységesnek a rendelkezésre álló források szerint. Ezt a korcsoportot a szépirodalom 12-18 évben, ${ }^{5}$ a pedagógia $18-22 / 25$ évben, ${ }^{6}$ a biológia 20-39 évben, ${ }^{7}$ a pszichológia 20-40 évben ${ }^{8}$ határozza meg, ami jelentős különbségeket jelent. Az Amerikai Diabetes Társaság (ADA: American Diabetes Association) is külön foglalkozik ezzel a kérdéskörrel és megállapítja, hogy a mai huszonévesek alapvető szempontok alapján (házasság, gyermekvállalás, munka) még nem a felnőttek életét élik, így a fiatal felnőttkor nem közvetlenül a serdülőkor után kezdődik. ${ }^{9}$ Az ADA ajánlásában a serdülő- és fiatal felnőttkor közötti életszakasz jellemzésére - a fejlődéspszichológia eredményeire támaszkodva ${ }^{10}$ - egy új, az ún. emerging adulthood, illetve az emerging adult fogalmát vezette be a diabetológiai gyakorlatba (amelyet „fejlődő felnőtt"-nek fordíthatunk), és amely a 18-30 éves korosztályra vonatkozik. Ennek értelmében, a fejlődő felnőttkor a serdülőkor meghosszabbításaként is értelmezhető, és napjainkban 30 év felett beszélhetünk „fiatal felnőtt”-ről. A serdülő/adoleszcens és a fiatal felnőtt korosztály közé tehát a fejlődő felnőtt korcsoport helyezendő be, ami alapján, amikor a diabeteses gyermek felnőttgondozásba való átadásáról/átvételéről beszélünk, akkor az ADA szerint azon azt kell értenünk, hogy az adoleszcens cukorbeteg átkerül a fejlődő felnőtt cukorbetegek ellátását végző szakellátóhelyre.

\section{A fiatal cukorbetegek gondozását befolyásoló körülmények}

A család szerepe alapvetően meghatározó a cukorbeteg gondozása tekintetében. Sikeres gondozásról és átadás-átvételről akkor beszélhetünk, ha a gyermekkortól a felnőttkorig terjedő hosszú, átmeneti időszakban a család szerepe minden életkorban optimális. Míg gyermekkorban a gondozás 
a család által irányított, meghatározott eseménysorozat („family-managed care”), ahol a család szerepe, támogatása csaknem teljes felelősséget jelent, addig az adoleszcens és az újabb adatok tükrében hozzátehetjük, hogy a fejlődő felnőtt esetében is a család szerepe fokozatosan átalakuló kapcsolatrendszer. Ebben az életkorban megkezdődik, majd egyre jobban kiteljesedik a családról való leválás, és a család támogatása egyfajta kontrolláló, felügyelői funkcióvá alakul, miközben az önmenedzselés folyamata egyre kifejezettebbé válik a feladatok megosztásával, átvételével („,shared care"). A fiatal felnőttkorra a páciens családhoz füződő viszonya teljesen átalakul, hiszen ekkor már a szociális és gazdasági önállóság feltételei is megvalósulnak, ahol a régi család (szülők, testvérek) új tagokkal (feleség, gyermekek) egészül ki, a család már csak támogató, segítő szerepet tölt be, és a diabeteses páciens a gondozás folyamatában önállóvá válik („self-care”). ${ }^{11}$

A serdülő cukorbeteg gondozása több szempontból eltér a gyermek gondozásától, hiszen a család szerepének megváltozásán túl előtérbe kerül a szülők eltérő hozzáállásának, a szülői stílusjegyeknek a jelentősége (parancsoló, tekintélyelvű, hajthatatlan vagy engedékeny, közönyös, gondatlan szülő), ${ }^{4}$ a tinédzser cukorbeteg részéről a barátoknak való megfelelés, amely a diabeteses serdülő számára mindennél (a diabetes kontrolljánál is) fontosabb lehet. Jellemzője ennek az időszaknak a jelentős anyagcsereromlás, az elhízás és a súlyos hypoglykaemiák megjelenése, gyakoribbá válása. Az anyagcsere romlása mögött az endokrin változásokon és az inzulinrezisztencia megjelenésén túl a rendszertelen életmód, étkezés és fizikai aktivitás, a rossz terápiás adherencia, az evészavarok és kockáztató viselkedésformák manifesztálódása legtöbbször tetten érhető. Ebben a korban várható a microés macroangiopathiás szövődmények szubklinikai formában való kialakulása, az alkoholfogyasztás, dohányzás és kábítószer-élvezet megjelenése, a járművezetés/jogosítványszerzés előtérbe kerülése, egyes pszichés és mentális zavarok (depresszió, evészavarok, addikció stb.) manifesztálódása.

A gondozás sikerességét alapvetően befolyásoló fenti tényezők megoldására nem rendelkezünk egységesen elfogadott és evidenciákkal alátámasztott módszerekkel. Az ISPAD ajánlása ${ }^{4}$ szerint a serdülők gondozási stratégiájának kialakítása során a betegedukációban a páciens és gondozói team közötti kölcsönös bizalomra építő, motiváló és sajátos kommunikációt megvalósító módszerekre kell támaszkodni. Törekedni kell az adoleszcens számára prioritást jelentő kérdések (pl. társaknak való megfelelés) megismerésére, amennyiben ezek a kezelés sikerességét negatívan befolyásolják, úgy a kicsi, de még elérhető célok megvalósítására kell törekedni. A szülői szerepkör megváltozásának elfogadásában fontos szerep hárul a gondozói teamre. Lényeges megértetni, hogy a szülői részvétel és támogatás a serdülőkor teljes egészében nélkülözhetetlen, azonban a teljes felelősségvállalást át kell, hogy vegye a kooperatív együttmüködés a diabeteses serdülővel. Mindezen célok elfogadtatásában más és más stratégiára és támogatásra van szükség és lehetőség az egyes szülői stílusjegyek függvényében, amelyekhez sokszor nem könnyủ alkalmazkodni, de ami nélkül csak kevés eredményre van kilátás. Az anyagcsere romlásának megakadályozása érdekében a sajátos élettani változásoknak megfelelő kezelési stratégia, étrend és inzulinadagolás kialakítása és adaptálása elkerülhetetlen, amivel párhuzamosan a szövődmények rendszeres szürésének bevezetése, ezen keresztül is a jó anyagcserére, a szövődmények elkerülésére való ösztönzésnek és törekvésnek nagy hangsúlyt kell kapnia. A pszichés és mentális zavarok, pszichiátriai kórállapotok kialakulásának veszélye miatt pszichológus, mentálhigiénés szakember bevonása a gondozási munkába számos alkalommal nem kerülhető el annak érdekében, hogy az esetleges pszichiátriai kezelés szükségessége kellő időben felismerhetővé váljon.

A ,fejlődő felnőtt” gondozásának nehézségeit az ADA egyik ajánlásában foglalja össze, amely nem meglepő módon az adoleszcens-gondozás során jelentkező problémákkal számos esetben összecseng. Kiemelendő, hogy a felnőttszakrendelésre átkerülő páciens alapvetően más környezetben találja magát. A korábban megszokott gyermekgyógyászati ellátás és a felnőttgyógyászati ellátás különbözőségei szembetűnőek és igen szokatlanok lehetnek (pl. idős betegtársak, számos 2-es típusú, szövődményes beteg, más helyszín, új személyzet stb.). Mindezek mellett a serdülőkor meghosszabbításaként is jellemezhető fejlődő felnőttkorra is jellemző a rossz anyagcserekontroll, az egyéb rizikófaktorok jelenléte, az akut szövődmények, 


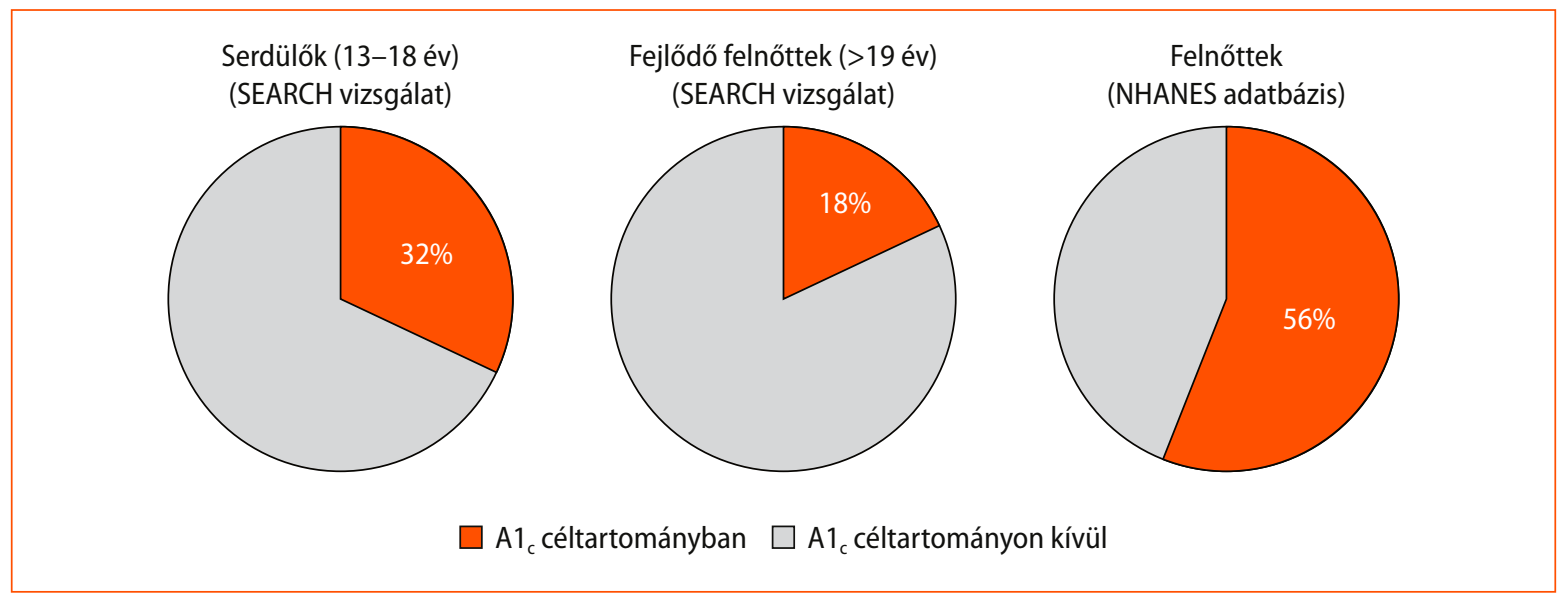

1. ábra. Anyagcserekontroll 1-es típusú cukorbeteg serdülők, fejlődő felnőttek és felnőttek körében

anyagcsere-kisiklások növekvő kockázata, a pszichoszociális problémák jelentkezése, a nemi élet és a reprodukciós funkciók zavarai, alkohol-, drogfogyasztás és dohányzás negatív hatásai. Ugyancsak központi kérdéskör a késői szövődmények megjelenése, kialakulásuk felgyorsulása. A nagy esetszámot feldolgozó amerikai felmérés szerint (SEARCH tanulmány: SEARCH for Diabetes in Youth Study) a serdülő korú betegek 32 százaléka volt a kezelési céltartományon belül, míg ugyanebben a vizsgálatban a fejlődő felnőtt betegeknek csupán 18 százaléka volt megfelelően kezelt. ${ }^{12}$ Ezzel szemben az ugyancsak észak-amerikai NHANES (National Health and Nutrition Examination Survey) adatbázis elemzése azt mutatta, hogy a felnőtt betegek mintegy 56 százaléka volt céltartományon. ${ }^{13}$ Mindez azt támasztja alá, hogy az anyagcserekontroll szempontjából a fejlődő felnőtt korú cukorbetegek vannak a legkedvezőtlenebb helyzetben (1. ábra).

Az ADA ajánlása, hangsúlyozva ennek a korosztálynak a veszélyeztetettségét, külön kiemeli

1. táblázat. Microvascularis szövődmények gyakorisága fiatal cukorbetegekben

\begin{tabular}{|c|c|c|}
\hline & T1DM & T2DM \\
\hline Perzisztáló microalbuminuria & $3-18 \%$ & $22 \%$ \\
\hline Korai nonproliferatív retinopathia & $12-49 \%$ & $36 \%$ \\
\hline Szubklinikai neuropathia & $7-71 \%$ & $50 \%$ \\
\hline
\end{tabular}

a fiatal páciensek esetében az átadás-átvétel időszakában a gondozásból való kiesés fokozott kockázatát. Hazai megfigyelés is rámutatott arra, hogy a gyermekgyógyászati ellátásból átkerült cukorbetegek esetében a retinopathia kifejlődése felgyorsul, ami számos esetben a gondozásból való átmeneti vagy végleges kieséssel magyarázható. ${ }^{14}$ Az irodalmi adatok a fiatal cukorbetegek (adoleszcens és fejlődő felnőtt betegek) esetében a microvascularis szövődmények gyakoriságát jelentős mértékűnek írják le, ami szintén a korosztály veszélyeztetettségét mutatja ${ }^{15,16}$ (1. táblázat).

\section{Az átadás-átvétel sikerét befolyásoló tényezők}

$\mathrm{Az}$ átadás-átvétel eredményességét számos tényező befolyásolja, amelyeket a 2. ábrán foglalunk öszsze. A sikeres átadás egészségnyereséggel párosul, ami a terápiás adherencia javulásában, a gondozás folyamatosságában, kedvezőbb anyagcserekontrollban, az akut és krónikus szövődmények elkerülésében nyilvánul meg.

Az átadás-átvétel sikerességének megítélése, tudományos igényű vizsgálata számos nehézségbe ütközik. Az obszervációs elemzések adatfelvételi és módszertani hibalehetőségek miatt korlátozott értékűek, az intervenciós vizsgálatok pedig a nem megfelelő kontrollcsoportok alkalmazása okán kevéssé értékelhetőek. A vizsgálatok eredményei is ellentmondásosak, azonban a tranzícióval 


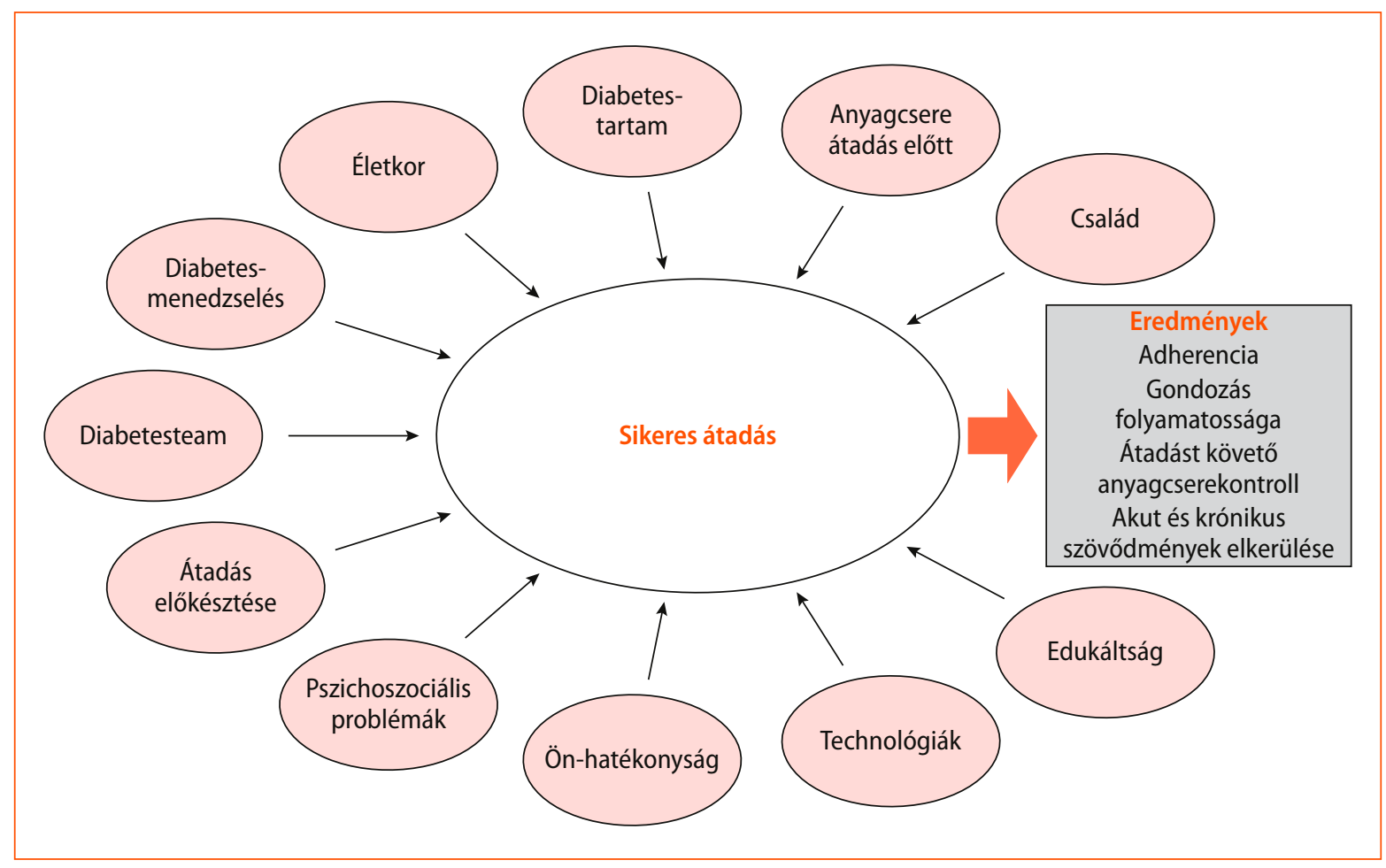

2. ábra. Az átadás-átvételt befolyásoló tényezők fejlődő felnőtt korú cukorbetegek esetében ${ }^{11}$

összefüggésben a viziteken való megjelenések gyakoriságának csökkenése általában megállapítható. ${ }^{17}$ A megfelelő intervenciós vizsgálatok hiányában jelenleg nem áll rendelkezésre evidenciákon alapuló módszer, amely egyértelműen sikerrel kecsegtet. Egy közelmúltban végzett vizsgálatban a közös gyermek- és felnőttgondozás eredményeit hasonlították össze a csak felnőttgondozáson szerzett tapasztalatokkal (joint transition clinic vs. young adult clinic) az átadás vonatkozásában. Az eredmények azt igazolták, hogy a közös gondozásra kerülő betegek anyagcseréje jobb volt, mint a csak felnőttgondozásra kerülő betegek esetében. Ebből a tanulmányból az is megállapítható volt, hogy a telefonos után-követést bevezető centrumokban a gondozásból való kiesési ráta, illetve a megjelenések aránya kedvezőbbé vált. ${ }^{18}$

Az átadás-átvételre vonatkozóan, mint említettük, kevés kontrollált tanulmány áll rendelkezésre, ezért az ajánlások alapvetően konszenzusos megállapításokra épülnek. Ilyen ajánlás napjainkban az ISPAD és az ADA ajánlása, ${ }^{4,9}$ amelyek alapján az alábbi fontosabb megállapítások emelhetők ki a gyakorlat számára. A diabeteses beteg gyermekdiabetológiai gondozásból felnőttdiabetológiai gondozásba való átadására időben fel kell készíteni az egész családot. Már legalább egy évvel a tervezett, illetve esedékes átadás előtt beszélni kell az átadásról, meg kell választani az átadás időpontját, amiben lehetőség szerint rugalmasnak kell lennünk, de figyelembe kell venni az érvényes jogszabályokat, rendeleteket, amelyek számos befolyásoló, illetve korlátozó tényezőt tartalmaznak (pl. 18 éves korhatár, közép-felsőfokú tanulmányok folytatása, munkába állás, táppénzjogosultságok, társadalombiztosítási támogatások és egyéb juttatások stb.). Meg kell ismertetni a beteget és a szülőket a felnőttgondozó munkájával, be kell mutatni a különbözőségeket, foglalkozni kell a szülői szerepkör további változásával, a felelősség fokozatos átruházásával. Lényeges szempont a megfelelő felnőttgondozó kiválasztása (lakhely, felsőoktatás helye, munkahely stb.) és annak megkeresése a gyermekgondozó által. Ideális esetben 


\section{2. táblázat. Ajánlások az átadáshoz (ISPAD és ADA ajánlások alapján)}

- Megfelelő felnőttgondozó kiválasztása, megkeresése

- Ideális: közös gyerek-felnőttgondozó

- Kapcsolat a két gondozó között: összekötő személy, szakápoló

- Előkészítés: beszélgetés az átadásról már legalább egy évvel korábban

- Rugalmas időpontválasztás, szülói felelősség fokozatos

átruházása, gondozók különbözőségének bemutatása

- Írásos dokumentumok (klinikai összefoglaló, gondozás tapasztalatai, kezelési protokollok)

- Alapellátás bevonása (házi gyermekorvos, családorvos, asszisztens, védőnő)

- Beteg követése (elvesztés lehetőségének minimalizálása)

- Vizitek átadás után: T1DM esetén 3 havonta, T2DM esetén 3-6 havonta

• Szövődmények vizsgálata

egy településen, illetve egymáshoz közel, akár egy intézményben működik a fogadó felnőttgondozó, és ilyen esetekben élő szakmai kapcsolat van a két szakellátóhely között. Ezekben az esetekben könnyebben megvalósítható egy összekötő személy közreműködése, aki általában a diabetológiai szakápoló személyzet tagja (az irodalom „transition coordinator”, „care ambassador”, „patient navigator" neveken említi), és aki személyesen bemutatja, megismerteti az új személyzet tagjaival a beteget és családját. Az ajánlásokban szerepel olyan rendszer is, ahol, mint említettük, az átadandó/átadott fiatal betegek számára „közös gyerekfelnőtt" gondozási munka folyik mindkét gondozói team tagjainak közreműködésével, és amire már hazánkban is van példa (MDT XXVI. Kongreszszus, Gyermekdiabetes Szekció ülése), ${ }^{19}$ amelynek természetesen földrajzi korlátai vannak. Lényeges eleme a tranzíciónak az írásos dokumentumok átadása, amely klinikai összefoglalók, gondozási tapasztalatok, kezelési protokollok továbbítását jelenti az átadó szakrendelés részéről. Az átadásnak nem megkerülhető eleme az alapellátás művelőinek (családorvos, házi gyermekorvos, asszisztens, védőnő) bevonása a folyamatba, akik a későbbiekben is részesei lesznek a beteg gondozásának. Minden betegkövetési eszközt fel kell használni annak elkerülése érdekében, hogy a páciens a gondozási rendszerből akár átmenetileg is kiessen (utánkövetés a felnőttgondozási helyen, telefonos utánkövetés stb.). Az átadás után az ajánlások 1-es típusú cukorbetegek esetében 3 havonként, 2-es típusú cukorbetegek esetében 3-6 havonként történő viziten való megjelenést javasolnak, a gyakoriság természetesen széles határok között mozog, de inkább a gyakoribb megjelenések preferálandók, főleg az első időszakban. Az említett szövődmények és társbetegségek megjelenésének fokozott kockázata miatt az átadást megelőzően elkezdett rendszeres szűrővizsgálatokat a további gondozás során is folytatni kell (2. táblázat).

A nemzetközi adatok és ajánlások alapján, de a hazai gyakorlatot és lehetőségeket figyelembe véve összefoglalásként elmondható, hogy a fiatal felnőttkor nem közvetlenül a serdülőkor után következik: a „fejlődő felnőttkor” az adolescens periódus meghosszabbítása. A szülők szerepe és a gondozás folyamata alapvetően átalakul a gyermekkor-felnőttkor határán. Fokozott kockázatot jelent a rossz anyagcsere, a szövődmények kialakulása, a kockázatkereső magatartás és a mentálhigiénés problémák. A legnagyobb veszélyt a beteg gondozásból való kiesése jelenti. Megtervezett, jól szervezett, individualizált és flexibilis átadásra van szükség, amelynek során az együttműködés az átadó és az átvevő gondozók között elengedhetetlen.

Közlésre érkezett: 2018. május 7.

Közlésre elfogadva: 2018. május 24.

A szerzö levelezési címe:

Prof. Dr. Barkai László

Pavol Jozef Šafárik Egyetem, Általános

Orvostudományi Kar, Gyermekgyógyászati Klinika

04011 Kassa, Trieda SNP 1, Szlovákia

E-mail: Barkai.L@t-online.hu 


\section{rrodalom}

1. Patterson CC, Dahlquist GG, Gyürüs E, Green A, Soltész G; EURODIAB Study Group: Incidence trends for childhood type 1 diabetes in Europe during 1989-2003 and predicted new cases 2005-20: a multicentre prospective registration study. Lancet 2009; 373: 2027-2033. doi:10.1016/50140-6736(09)60568-7

2. Pinhas-Hamiel 0 , Dolan LM, Daniels SR, Standiford D, Khoury PR, Zeitler P. Increased incidence of non-insulin-dependent diabetes mellitus among adolescents. J Pediatr 1996; 128: 608-615. doi:10.1016/50022-3476(96)80124-7

3. World Health Organization: Young people's health - a challenge for society. Report of a WHO Study Group on Young People and "Health for All by the Year 2000". Technical Report Series, 731. World Health Organization, Geneva, 1986. http://whqlibdoc.who.int/trs/WHO_TRS_731.pdf

4. Cameron FJ, Amin R, de Beaufort C, Codner E, Acerini CL: ISPAD Clinical Practice Consensus Guidelines - 2014: Diabetes in adolescence. Pediatric Diabetes 2014; 15(Suppl. 20): 245-256. doi:10.1111/pedi.12169

5. A Young Adult Library Services Association (YALSA) bemutatkozó oldala. http://www.ala.org/yalsa/aboutyalsa

6. Az MIT Young Adult Development Project bemutatkozó oldala. http://hrweb.mit.edu/worklife/youngadult/about.html

7. Human development. https://en.wikipedia.org/wiki/Human_development (biology)

8. McLeod SA: Erik Erikson. http://simplypsychology.org/Erik-Erikson.html

9. Peters A, Laffel L, and the American Diabetes Association Transitions Working Group: Diabetes care for emerging adults: Recommendations for transition from pediatric to adult diabetes care systems. Diabetes Care 2011; 34 : 2477-2485. doi:10.2337/dc11-1723
10. Arnett J): Emerging adulthood. A theory of development from the late teens through the twenties. Am Psychol 2000; 55: 469. doi:10.1037/0003-066X.55.5.469

11. Garvey KC, Markowitz JT, Laffel LM: Transition to adult care for youth with type 1 diabetes. Curr Diab Rep 2012; 12:533-541. doi:10.1007/s11892-012-0311-6

12. Petitti DB, Klingensmith GJ, Bell RA, Andrews IS, Dabelea D, Imperatore G, et al.; SEARCH for Diabetes in Youth Study Group. Glycemic control in youth with diabetes: the SEARCH for diabetes in Youth Study. J Pediatr 2009; 155: 668-672. doi:10.1016/j.jpeds.2009.05.025

13. Hoerger TJ, Segel JE, Gregg EW, Saaddine JB: Is glycemic control improving in U.S. adults? Diabetes Care 2008; 31: 81-86. doi:10.2337/dc07-1572

14. Vincze P, Madácsy L, Barkai L: Diabeteses mikroangiopathia vizsgálata gyermekkortól követett inzulin-dependens fiatal felnōtt betegeken. Magyar Belorvosi Archivum 1990; 43: 199-204.

15. Donaghue KC, Wadwa RP, Dimeglio LA, Wong TY, Chiarelli F, Marcovecchio ML, Salem M, Raza J, Hofman PL, Craig ME. Microvascular and macrovascular complications in children and adolescents. Pediatric Diabetes 2014; 15(Suppl. 20): $257-269$. doi: $10.1111 /$ pedi.12180

16. Barkai L, Gurieva I, Stirban A, Tesfaye S, Czupriak L, Mankovsky BN, et al.: Microvascular complications in children and adolescents with type 1 diabetes. Diabetes Stoffw Herz 2012; 21: 309-315.

17. Lyons SK, Becker DJ, Helgeson VS: Transfer from pediatric to adult health care: effects on diabetes outcomes. Pediatr Diabetes 2014; 15: 10-17. doi: $10.1111 /$ pedi. 12106

18. Gill G, Nayak AU, Wilkins J, Hankey J, Raffeeq P, Varughese GI, et al.: Challenges of emerging adulthood-transition from paediatric to adult diabetes. World J Diabetes 2014; 15: 630-635. doi:10.4239/wjd.v5.15.630

19. Fürst A, Stényer F: A diabeteses gyermek átadása a gyermekgondozásból a felnőttellátásba. Diabetologia Hungarica 2018;26(Suppl 1): 30-31. 